\title{
Změny předpisů pro oceňování věcí nemovitých od 1. srpna 2019
}

\section{Amendments to the Valuation of Immovable Property from 1 August 2019}

\author{
Albert Bradáč , Petr Polák \\ Vysoké učeni technické v Brně, Ústav soudního inženýrstvi
}

\author{
Abstrakt \\ V článku jsou uvedeny a komentovány změny oceňování nemovitostí, \\ které přináší novela č. 188/2019 Sb. oceňovací vyhlášky č. 441/2013 Sb. \\ Klíčová slova: nemovitost, nemovitá věc, stavba, právo stavby, pozemek, \\ věcné břemeno, cena.
}

\section{1. ÚVODEM}

K 1. srpnu 2019 nabyla účinnosti vyhláška Ministerstva financí č. 188/2019 Sb., jež novelizuje vyhlášku č. 441/2013 Sb., k provedení zákona o oceňování majetku (oceňovací vyhlášku), ve znění vyhlášek č. 199/2014 Sb., č. 345/2015 Sb., č. 53/2016 Sb., č. 443/2016 Sb. a č. 457/2017 Sb. Účelem předkládaného příspěvku je seznámit čtenáře podrobněji s touto novelou, včetně důvodů, jež k jejímu vydání vedly. V příspěvku jsou místy použity výňatky a grafy z důvodové zprávy MF ČR.

Zákon o oceňování majetku č. 151/1997 Sb. má obecnou povahu. Vymezuje základní pojmy, způsoby a principy oceňování a v podrobnostech potřebných pro ocenění odkazuje na prováděcí předpis, kterým je oceňovací vyhláška č. 441/2013 Sb. Tato stanovuje základní ceny, postupy výpočtu, charakteristiky znaků a jejich kvalitativní pásma, hodnoty, přirážky a srážky. Pro objektivnost oceňování nemovitých věcí je oceňovací vyhláška pravidelně aktualizována $\mathrm{v}$ návaznosti na vývoj cen na trhu s nemovitými věcmi v České republice a na změny právních předpisů, které se promítají do oblasti oceňování (např. stavební předpisy, občanský zákoník aj.); aktualizují se základní ceny, oceňovací postupy a terminologie. V novelách oceňovací vyhlášky se zohledňují také konstruktivní připomínky vznesené odbornou veřejností a poznatky pracovníků finančních úřadů, vycházející z aplikace oceňovacího předpisu v praxi, a ze znalostí místních podmínek. Aktualizace základních cen a úpravy oceňovacích postupů pro určování zjištěné ceny nemovitých věcí

\section{Abstract}

The article listed property valuation changes introduced by the new valuation Decree No. 188/2019 Coll.

Keywords: property, real thing, building, construction law, land, easements, price.

vychází z prováděných analýz údajů z prodejů nemovitých věcí, předávaných Ministerstvu financí dle ustanovení $§ 33$ odstavec 3 zákona o oceňování majetku finančními úřady, a jejich statistického vyhodnocení.

Hlavní změny provedené novelou č. 188/2019 Sb. jsou následující:

- oceňování pozemků v plochách koridorů veřejné dopravní nebo technické infrastruktury vymezených v územním plánu; dotýká se jak oceňování pozemků jiných, tak v návaznosti i pozemků zemědělských a lesních,

- úprava opotřebení u stavby vyhovující právu stavby pro oceňování práva stavby,

- úprava ocenění lesních porostů zohledňující plošně odumírající a plošně odumřelé porosty,

- aktualizace základních (jednotkových) cen stavebních pozemků vyjmenovaných obcí, oblastí nebo okresů,

- aktualizace základních (jednotkových) cen staveb pro jejich oceňování porovnávacím způsobem,

- aktualizace koeficientů změn cen staveb $\mathrm{K}_{\mathrm{i}}$ dle údajů z Českého statistického úřadu.

Přestože Evropské oceňovací standardy (EVS) i mezinárodní oceňovací standardy (IVS) nejsou pro Českou republiku závazné, jednotlivé základní způsoby oceňování uplatněné v oceňovacích predpisech jsou plně v souladu se způsoby, které jsou v těchto předpisech zakotveny. Uplatňují se tři základní způsoby oceňování - způsob nákladový, výnosový a porovnávací. 
Ve specifikovaných případech se použije kombinace způsobu nákladového a výnosového.

Oceňování staveb nákladovým způsobem určuje cenu věci, za kterou by se dala stejná nebo obdobná věc postavit k datu ocenění; vychází z nákladů na provedení stavby. Pro ocenění jsou určeny základní ceny podle druhu a účelu užití stavby, použitých materiálů a stavebnětechnického provedení. Postupy a principy výpočtu byly zakotveny ve vyhlášce č. 178/1994 Sb., o oceňování staveb, pozemků a trvalých porostů, ve znění pozdějších předpisů. Nastavený postup výpočtu vyhovuje účelům oceňovací vyhlášky; zachování tohoto systému umožňuje sledování vývoje cen v této oblasti. Ceny staveb se upravují na aktuální cenovou hladinu koeficienty změn cen staveb Ki, které jsou každoročně novelizovány. Tyto údaje jsou Ministerstvu financí předávány Českým statistickým úřadem. Hodnoty koeficientů změny cen staveb Ki odráží změny, k nimž došlo v oblasti cen v prríslušném tržním segmentu u daných typů (účelů užití) budov na trhu s nemovitými věcmi.

Výnosový způsob oceňování se uplatňuje především u nemovitých věcí, které jsou určeny k pronájmu nebo propachtování, nebo které jsou schopny generovat výnos. Principem výnosového způsobu je převedení budoucích výnosů $\mathrm{z}$ pronájmu věci (future value) na současnou hodnotu (present value) $\mathrm{k}$ datu jejich ocenění. Míra kapitalizace pro ocenění se určuje podle účelu užití stavby.

Porovnávací způsob vyjadřuje hodnotu věci z pohledu trhu, kdy cena věci se určuje $z$ porovnání cen dosažených při prodejích stejných nebo srovnatelných věcí, za stejných nebo obdobných podmínek, k datu ocenění. Porovnávací způsob pro nemovité věci, uplatněný v oceňovací vyhlášce, je založen na nepřímém porovnání, tzn. že vychází z porovnání s referenčním vzorkem (nemovitou věcí obvyklých charakteristik). Podle druhů nemovitých věcí a jejich hlavních cenotvorných charakteristik jsou pro porovnání stanoveny znaky a jejich kvalitativní pásma.

Kombinovaný způsob v oceňovací vyhlášce vychází z ocenění nemovitých věcí nákladovým a výnosovým způsobem. Uplatňuje se u těch druhů nemovitých věcí, jejichž cena se určuje nákladovým způsobem podle ustanovení § 12 oceňovací vyhlášky, a to za podmínky, že k datu ocenění jsou nebo mohou být tyto nemovité věci pronajaty, a to u určeného účelu užití budov a hal, resp. u částečně pronajatých popř́ípadě nepronajatých, pokud jejich stavebně technický stav pronájem umožňuje. U nepronajatých ploch se ve výpočtu uplatňuje obvyklé nájemné. Pro ocenění je použita kapitalizační metoda s předpokladem konstantního čistého ročního výnosu. Metoda vychází z rozdílu cen stavby určených výnosovým a nákladovým způsobem, dále z rozvojových možností stavby a předpokládaných změn, které mají vliv na výši sjednávaných cen. Cílem návrhu novely je též úprava oceňování pozemků, nacházejících se ve vymezené ploše koridoru pro veřejnou dopravní a technickou infrastrukturu. Z podnětu Ministerstva dopravy vyplynulo, že současný stav oceňování těchto pozemků není optimální. Z hlediska objektivity jejich ocenění bylo potřeba provést úpravu oceňovací vyhlášky pro zařazení těchto pozemků podle účelu užití.

Dále byly provedeny některé doplňující a vysvětlující textové úpravy, jako např́íklad u oceňování jednotek nebo určování počtu obyvatel v obcích.

Oprávnění Ministerstva financí vydávat v mezích své působnosti vyhlášky vyplývá z čl. 79 odst. 3 Ústavy České republiky, podle kterého ministerstva, jiné správní úrudy a orgány územní samosprávy mohou na základě a $\mathrm{v}$ mezích zákona vydávat právní předpisy, jsou-li k tomu zákonem zmocněny. Zároveň je třeba dodržovat ustanovení čl. 11 odst. 5 Listiny základních práv a svobod, nebot' ocenění podle oceňovací vyhlášky se uplatňuje v daňové oblasti (např. jako základ daně).

Ponechání vymezení postupu oceňování a aktualizace základních cen pro určování zjištěné ceny na úpravě prováděcí vyhlášky je odůvodnitelné rozsahem a komplexností tohoto postupu, dále potřebou zajistit pružnou reakci na změny cen na trhu nemovitých věcí a změny v právních předpisech dotýkající se oblasti oceňování. Oblast oceňování majetku není upravena sekundárním právem Evropské unie a obecně nepodléhá harmonizaci na úrovni Evropské unie. Evropské oceňovací standardy (EVS) i mezinárodní oceňovací standardy (IVS) nejsou pro Českou republiku závazné, ale pouze doporučené. V oblasti obecných právních zásad práva Evropské unie nemůže docházet $\mathrm{k}$ jakékoliv diskriminaci na základě státní př́slušnosti, pohlaví osob, omezování volného pohybu osob, služeb a kapitálu nebo svobody usazování, nebot' navrhovaná právní úprava je normou technickou, která se pouze přizpůsobuje situaci na trhu, zde na trhu s nemovitými věcmi.

Právní úprava není s těmito principy v rozporu, je tedy plně slučitelná s předpisy Evropské unie, její judikaturou a obecnými zásadami práva Evropské unie. Není novelou nařízení vlády, ale novelizuje prováděcí vyhlášku $\mathrm{k}$ zákonu o oceňování majetku v návaznosti na vývoj sjednávaných cen na trhu s nemovitými věcmi. Nemá vliv na podnikatelské prostředí, státní rozpočet, ostatní veřejné rozpočty, dále nemá vliv na specifické skupiny obyvatel včetně národnostních menšin či specifické skupiny obyvatel, ani na životní prostředí; jedná se především o parametrické změny, vedoucí $\mathrm{k}$ prriblížení zjištěné ceny co nejvíce cenám sjednaným na volném trhu.

Současný právní předpis, ani jeho novela, nemá vliv na vztah mužů a žen a ani nezakládá jiné diskriminační prostředí. Jedná se především o technickoekonomickou normu v oblasti oceňování, jejímž účelem je určování cen, především pro daňové účely, při kterém se vychází z číselných databází cenových údajů a jejich analýzy. Stávající právní úprava i novela vychází z vyhodnocení statistických údajů v oblasti sjednávaných cen nemovitých věcí. Oceňovací postupy u jednotlivých způsobů oceňování vycházejí z obecných zásad, které jsou běžně užívány i při oceňování pro jiné účely. Z uvedeného lze dovozovat, že úpravy provedené v novele nemají a ani nemohou mít negativní dopad na ochranu soukromí ani na ochranu osobních údajů.

Přiblížení zjištěných cen $\mathrm{k}$ cenám na trhu výrazně usnadňuje výkupy nemovitých věcí. Odpadá tím zdlouhavé jednání s jejich vlastníky, které je $\mathrm{v}$ opačném případě nutno řešit vyvlastňovacím řízením, kterým dochází ke zdržování zahájení staveb a jejich zdražování. Oceňovací vyhláška slouží také jako srovnávací hladina k úrovni sjednávaných cen, čímž její adekvátní ceny v poměru k cenám sjednaným usnadňují jednání s poplatníky při daňovém ř́zení.

\section{K OCEŇOVÁNÍ POZEMKŮ}

\section{\$ 1 - Předmět úpravy: beze změn.}

$\$ 2$ - Cenová mapa stavebních pozemků: beze změn.

\$ 3 - Stavební pozemek neoceněný v cenové mapě stavebních pozemků: beze změn. 
Příloha č. 1 (Měření a výpočet výměr staveb a jejich částí): beze změn.

Př́íloha č. 2: V příloze jsou změny:

- v tab. 1 jsou aktualizovány základní ceny za $\mathrm{m}^{2}$ stavebního pozemku ve vyjmenovaných obcích, jejich oblastech a okresech na základě sjednávaných cen a analýz údajů, které MF předávají územní pracoviště Finančních úřadů v návaznosti na ustanovení § 33 odstavec 3 zákona o oceňování majetku (viz mj. obr. 1 až 3 a tab. 1),

- $\quad \mathrm{v}$ tab. 2 této prrílohy byly sníženy hodnoty některých znaků.

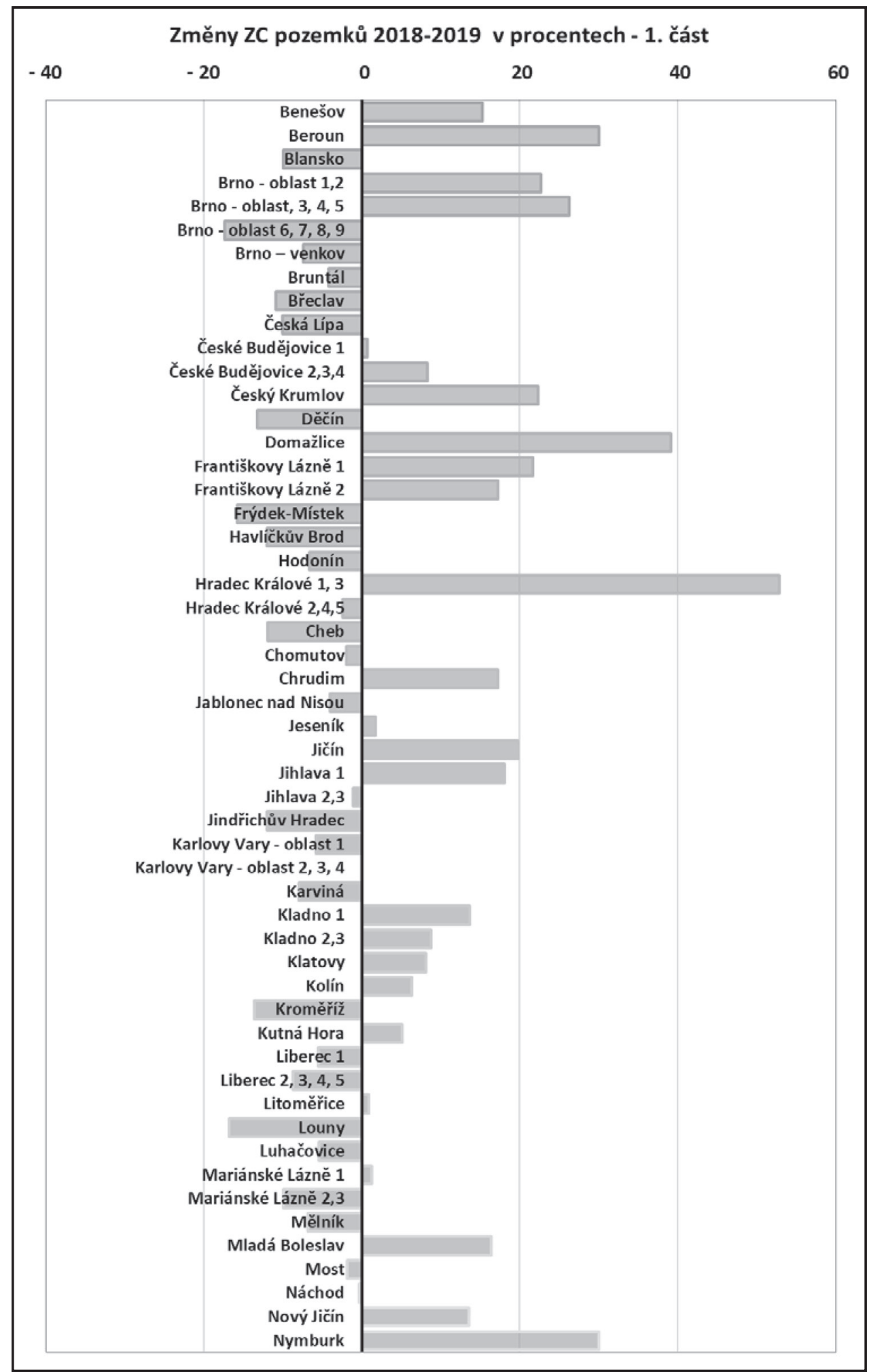

Obr. 1 Změny základních cen pozemkủ 2018/2019 u vyjmenovaných obcí resp. jejich částí v tabulce č. 1 v přiloze č. 2 oceňovací vyhláškyčást 1 (Zpracování: vlastni).

Fig. 1 Changes in the basic price of the land, 20187/2019 at the listed municipalities or their parts in table 1 in the annex no. 2 to the valuation of the decree - part 1 (Handle: custom). 


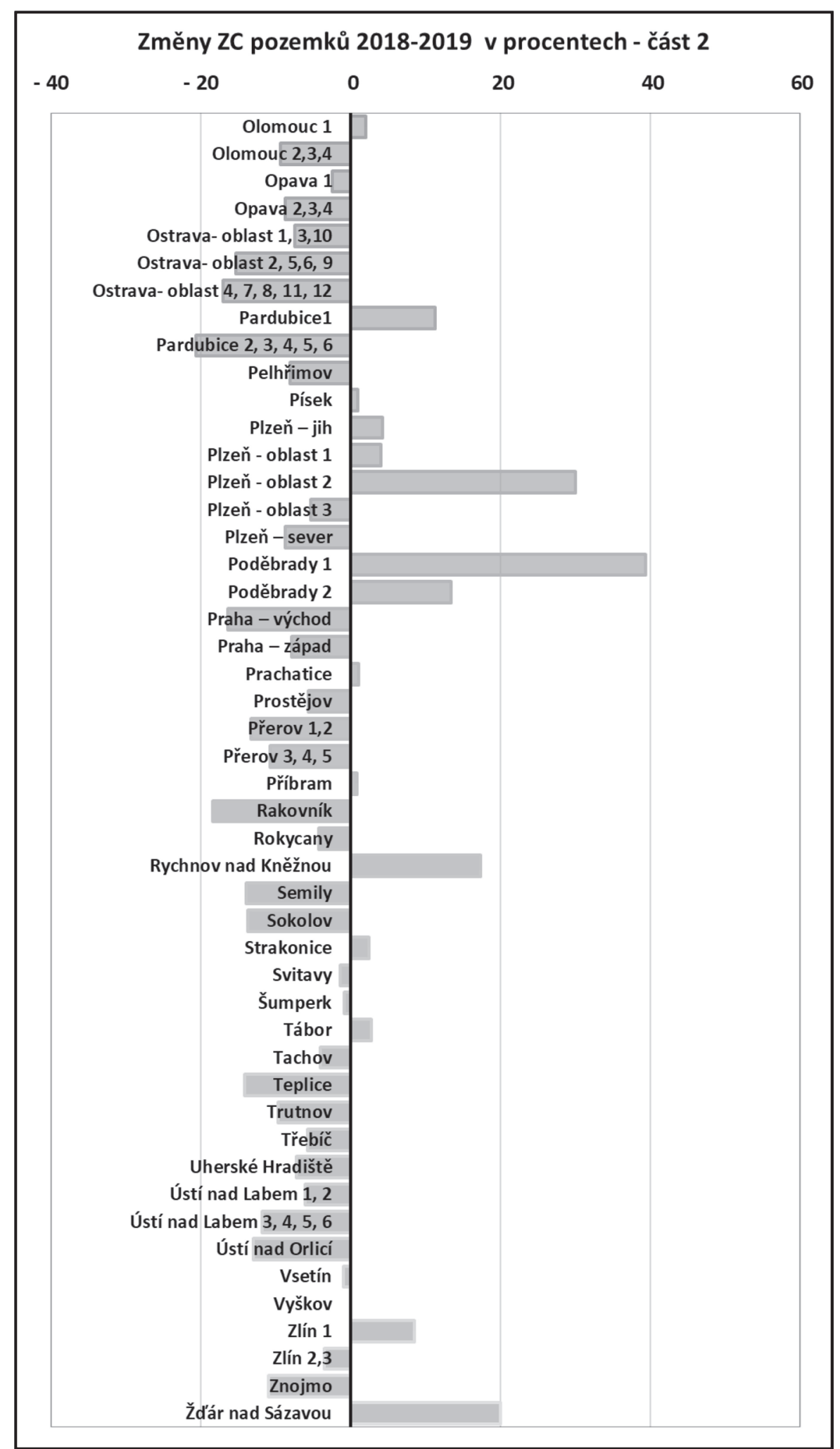

Obr. 2 Změny základních cen pozemkủ 2018/2019 u vyjmenovaných obcí resp. jejich částí v tabulce č. 1 v přiloze č. 2 oceňovaci vyhláškyčást 2 (Zpracování: vlastní).

Fig. 2 Changes in the basic price of the land, 2018/2019 at the listed municipalities or their parts in table 1 in the annex no. 2 to the valuation of the decree - part 2 (Handle: custom). 
Tab.1 Změny základních cen stavebních pozemků 2018/2019 - Praha. Oblasti podle přilohy č. 2 oceňovaci vyhlášky (Zpracování: vlastní). Tab.1 Changes in basic prices of building plots, 2018/2019 - Prague. Areas according to Annex 2 of the valuation decree (Handle: custom).

\begin{tabular}{|c|c|c|c|c|}
\hline Praha oblast & Katastrální území & 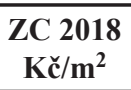 & $\begin{array}{l}\text { ZC } 2019 \\
\text { Kč } / \mathbf{m}^{2}\end{array}$ & $\begin{array}{l}\text { Změna ZC } \\
\%\end{array}$ \\
\hline 1 & Hradčany, Josefov, Malá Strana, Nové Město, Staré Město & 50310 & 65075 & $+29,35$ \\
\hline 2 & Vinohrady, Vyšehrad & 15120 & 17002 & $+12,45$ \\
\hline 3 & Holešovice, Karlín, Žižkov & 15120 & 17002 & $+12,45$ \\
\hline 4 & Braník, Hodkovičky, Krč, Lhotka, Michle & 7814 & 7999 & $+2,37$ \\
\hline 5 & Hlubočepy, Jinonice, Košíře, Motol, Radlice & 7814 & 7999 & $+2,37$ \\
\hline 6 & Břevnov, Bubeneč, Dejvice, Troja, Střešovice, Veleslavín & 15120 & 17002 & $+12,45$ \\
\hline 7 & Ď́alice, Kbely, Letňany & 6083 & 6126 & $+0,71$ \\
\hline 8 & Bohnice, Čimice, Dolní Chabry, Lysolaje, Sedlec, Suchdol & 5186 & 5134 & $-1,00$ \\
\hline 9 & Libeň, Hloubětín, Kobylisy, Prosek, Střížkov, Vysočany & 7814 & 7999 & $+2,37$ \\
\hline 10 & Hrdlořezy, Malešice, Strašnice, Záběhlice & 7814 & 7999 & $+2,37$ \\
\hline 11 & $\begin{array}{l}\text { Dolní Měcholupy, Háje, Horní Měcholupy, Hostivař, Chodov, Petrovice, } \\
\text { Štěrboholy, }\end{array}$ & 6083 & 6126 & $+0,71$ \\
\hline 12 & $\begin{array}{l}\text { Benice, Kamýk, Komořany, Kunratice, Křeslice, Libuš, Modřany, Pitkovice, } \\
\text { Šeberov, Újezd u Průhonic }\end{array}$ & 6083 & 7999 & $+31,50$ \\
\hline 13 & Cholupice, Královice, Lipany, Nedvězí, Písnice, Točná & 5186 & 5134 & $-1,00$ \\
\hline 14 & $\begin{array}{l}\text { Běchovice, Dolní Počernice, Dubeč, Hájek u Uhříněvsi, Koloděje, Kolovraty, } \\
\text { Uhř́něves }\end{array}$ & 5186 & 5134 & $-1,00$ \\
\hline 15 & Březiněves, Čakovice, Miškovice, Satalice, Třeboradice, Vinoř, & 5186 & 5134 & $-1,00$ \\
\hline 16 & Radotín, ̌̌eporyje, Zbraslav, & 5186 & 5134 & $-1,00$ \\
\hline 17 & Lahovice, Lipence, Lochkov, Přední Kopanina, Sobín, Zadní Kopanina, & 5186 & 5134 & $-1,00$ \\
\hline 18 & $\begin{array}{l}\text { Holyně, Malá Chuchle, Řepy, Slivenec, Stodůlky, Třebonice, Velká Chuchle, } \\
\text { Zličín, }\end{array}$ & 6083 & 7999 & $+31,50$ \\
\hline 19 & Černý Most, Horní Počernice, Hostavice, Klánovice, Kyje, Újezd n. Lesy & 5186 & 5134 & $-1,00$ \\
\hline 20 & Liboc, Nebušice, Ruzyně, Vokovice, & 6083 & 6126 & $+0,71$ \\
\hline 21 & Nusle, Podolí, Smíchov, Vršovice & 7814 & 17002 & $+117,58$ \\
\hline
\end{tabular}

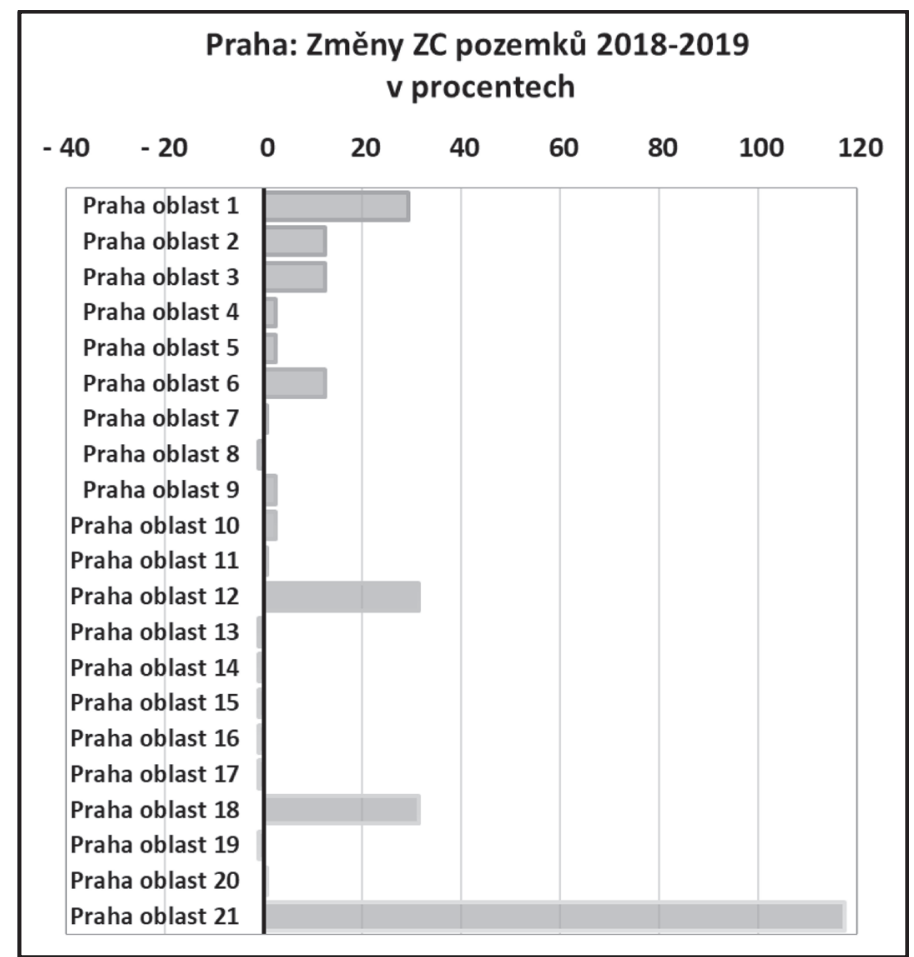

Obr. 3 Zmény základních cen stavebnich pozemků 2018/2019- Praha. (Zpracování: vlastní).

Fig. 3 Changes in basic prices of building plots, 2018/2019-Prague (Handle: custom). 


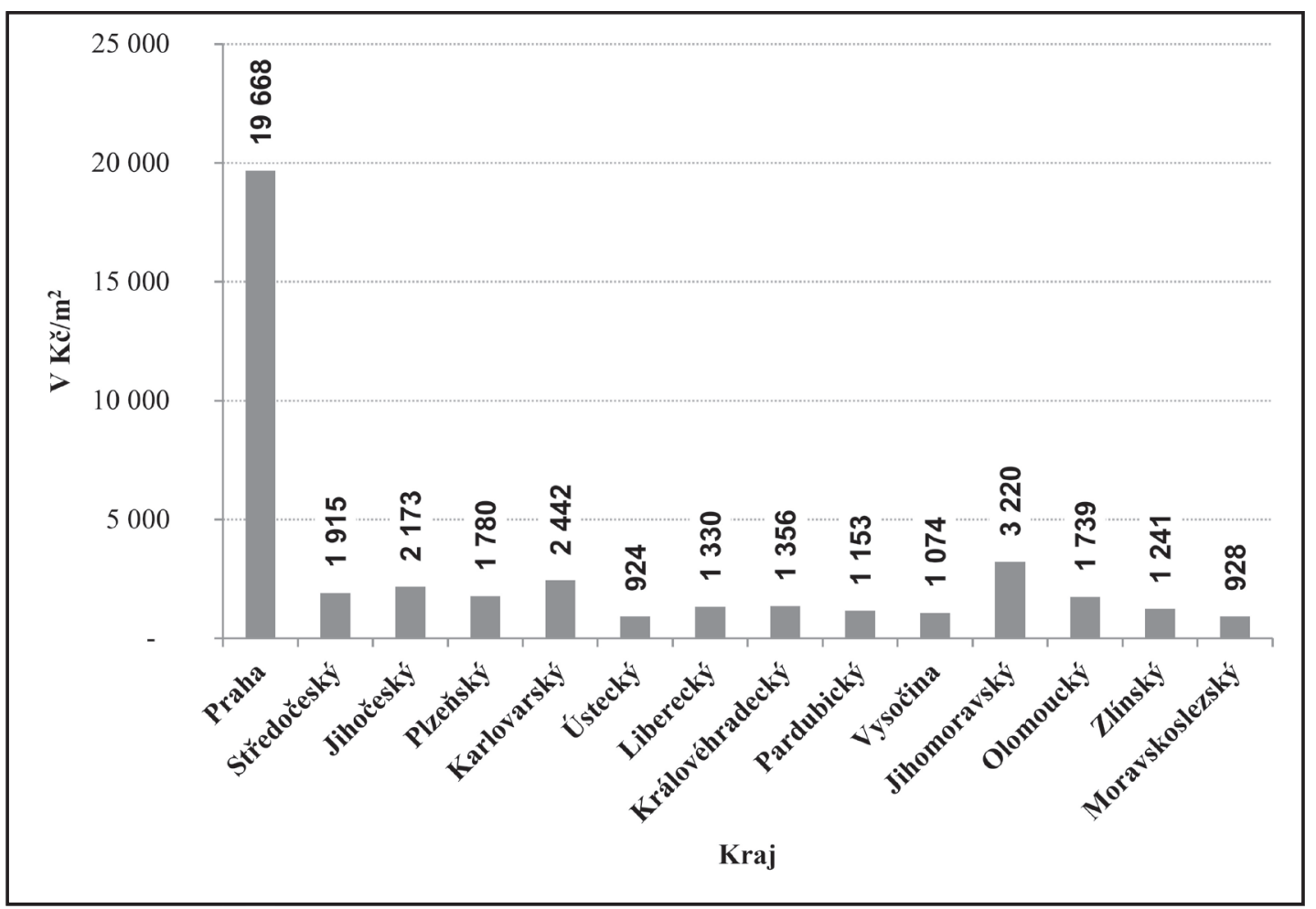

Obr. 4 Prüměrná cena stavebnho pozemku v kraji v Kč $/ m^{2}$ (Pramen: Dưvodová zpráva MF ČR 2019).

Fig. 4 Average price of a building land in the region in $C Z K / m^{2}$ (Source: Explanatory Memorandum of the Ministry of Finance 2019).

Průměrné jednotkové ceny stavebních pozemků v jednotlivých krajích ČR vyjadřuje graf na obr. 4 . Z grafu vyplývá, že průměrné jednotkové ceny stavebních pozemků sjednávané v hl. m. Praze jsou několikanásobně vyšší než tyto ceny v ostatních krajích ČR. Nejnižší ceny jsou naopak v kraji Ústeckém a Moravskoslezském.

\$ 4 (Základní cena upravená stavebního pozemku): beze změn.

\$ 5 - Společná ustanovení pro stavební pozemek neuvedený v CMSP: beze změn.

§ 6 - Zemědělský pozemek - nové odstavce č. 1 a 2 .

Plocha koridoru veřejné dopravní nebo technické infrastruktury, vymezená v územním plánu, není určena celá k zastavění, ale jedná se pouze o plochu pro umístění stavby. Účelem vymezení koridoru je „blokování“ území pro budoucí liniovou stavbu, a proto nelze pozemek ve vymezené ploše koridoru považovat za rovnocenný s pozemkem ve vymezené ploše určené v územním plánu $\mathrm{k}$ zastavění. Z hlediska objektivity je zařazení pozemku, nacházejícího se v koridoru, mezi jiné pozemky jako pozemky určené k zastavění nesprávné, nebot' plánovaná výstavba se bude realizovat pouze na části plochy koridoru. $\mathrm{V}$ případech koridorů veřejné technické infrastruktury budou ve většině př́padů pozemky využívány stejným způsobem jako před realizací předmětné stavby. Dle ustanovení $\S 9$ odst. 4 zákona o oceňování majetku se tyto pozemky nestanou pozemky stavebními.

Vuhůedem $\mathrm{k}$ výše uvedenému bylo nutno upravit text ustanovení $§ 9$ pro oceňování jiných pozemků, ustanovení pro oceňování pozemku zemědělského (ustanovení § 6) a pozemku lesního (ustanovení $\S 7)$ umístěného ve vymezené ploše koridoru. Pozemky se budou oceňovat podle skutečného využití, bez ohledu na jejich umístění $\mathrm{v}$ ploše koridoru.
Př́ilohy č. 4 (BPEJ) a č. 5 (Úprava ZC zemědělských pozemků) jsou beze změn.

§ 7 - Lesní pozemek a nelesní pozemek s lesním porostem: nové odstavce č. 1 a 2 (zdůvodnění viz výše u $§ 6$ ).

$\$ 8$ - Pozemek vodní plochy - beze změn

§ 9 - Jiný pozemek: V § 9 odst. 4 písmeno a) se za slova „určený k zastavění“ vkládají slova „, kromě pozemku, který je alespoň částečně součástí vymezené plochy koridoru veřejné dopravní nebo technické infrastruktury“; po doplnění zní:

„a) který je zahrnut do platného územního plánu nebo platného regulačního plánu jako pozemek určený k zastavění, kromě pozemku, který je alespoň částečně součástí vymezené plochy koridoru veřejné dopravní nebo technické infrastruktury, nebo část nezastavěného pozemku, určeného k zastavění vydaným územním rozhodnutím, ale kterou nelze zastavět $\mathrm{z}$ důvodu stanovení nejvyšší př́ípustné zastavěnosti, je cena určená podle $\S 4$ odst. 1 vynásobená koeficientem 0,30 , nelze-li jej ocenit podle písmene b) nebo c),"“

\section{OCEŇOVÁNÍ STAVEB NÁKLADOVÝM ZPU゚SOBEM}

§ 10 až 30 - text všech ustanovení je beze změn s výjimkou § § 21 (Oceňování jednotek), kde se doplňuje nový odstavec 6, který zní: „,(6) Spoluvlastnický podíl na pozemku či na pozemcích a poprípadě na trvalých porostech se oceni samostatně podle částí druhé a páté. “.

§ 29a - V návaznosti na doplnění přílohy č. 21 o určování opotřebení stavby, která vyhovuje právu stavby, při stanovení výše náhrady při zániku práva stavby, bylo upraveno i ustanovení § 29a, 


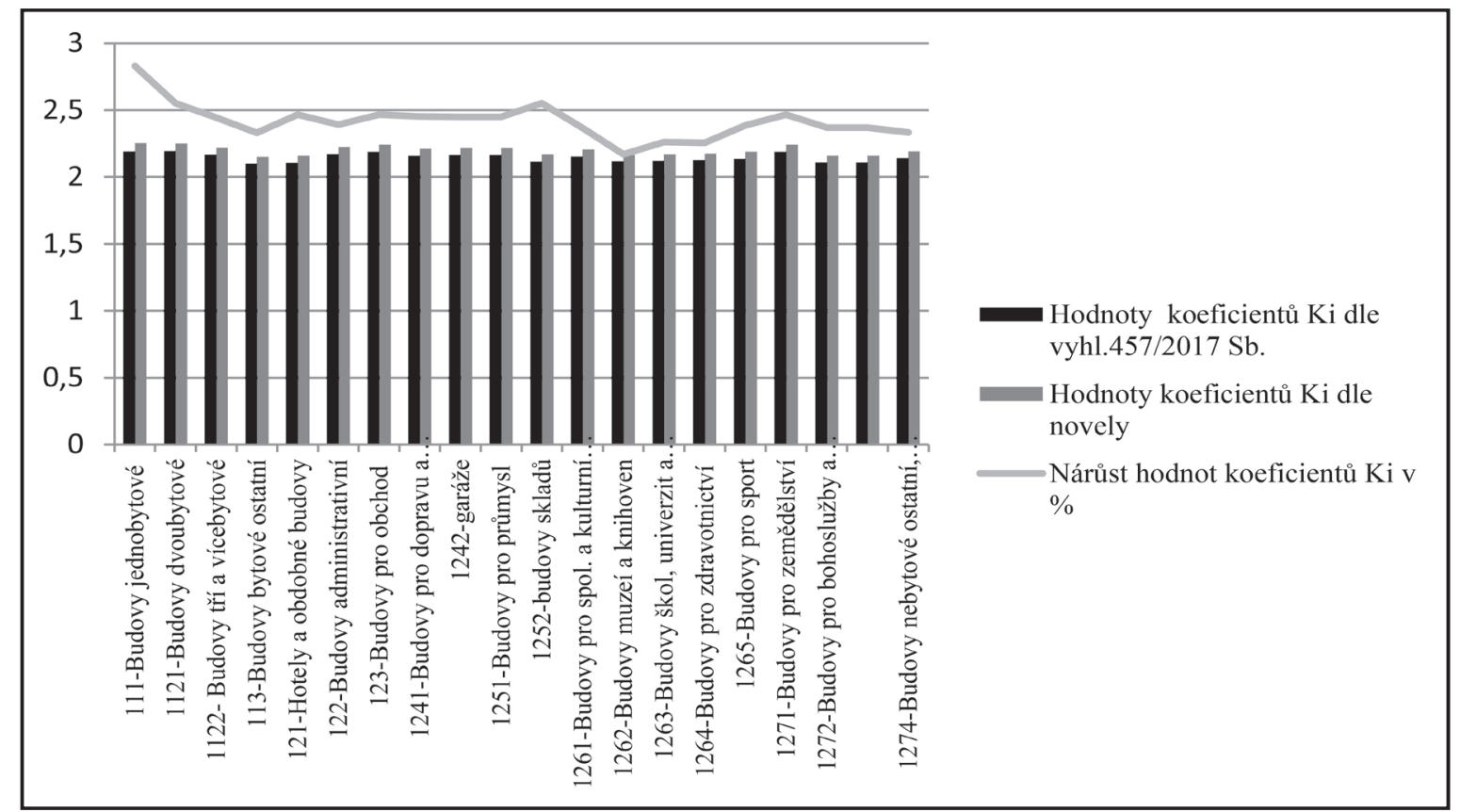

Obr. 5 Meziroční růst cen budov v návaznosti na změnu hodnoty koeficientu Ki (Pramen: Důvodová zpráva MF ČR 2019). Fig. 5 Year-on-year rise in building prices following a change in the Ki value

(Source: Explanatory Memorandum of the Ministry of Finance 2019).

podle kterého se určuje cena stavby, popř́padě jednotky, které jsou součástí práva stavby. Ustanovení nyní zní: Cena stavby, popřipadě jednotky, které jsou součástí práva stavby, se urči podle $\$ 10$ až 30. To neplatí v prípadě ocenéni stavby pro určení výše náhrady, pokud bylo ve smlouvě ujednáno jinak.

Přílohy č. 8 až 21, týkající se nákladového ocenění staveb, jsou beze změn.

Př́loha č. 41 - Koeficienty změn cen staveb u nákladového ocenění $-\boldsymbol{K}_{\mathbf{i}}$ :

Úprava aktualizuje hodnoty koeficientů změn cen staveb (meziroční inflační koeficient nárůstu cen stavebních prací), které každoročně poskytuje v hodnotách za 1. pololetí aktuálního roku Český statistický úřad. Dále byly provedeny některé úpravy textu v souladu s aktualizací položek Klasifikace stavebních děl CZ-CC k 1. lednu 2019 a napřr. nové začlenění golfových hřišt' do kódu položky 241213 (do 31. 12. 2018 byly vedeny v kódu 241113).

Hodnoty koeficientů změny cen staveb Ki u budov v roce 2018 a hodnoty pro rok 2019 v členění podle účelu jejich užití a meziroční procentní nárůst hodnot vyjadřuje graf na obr. 4.

Průběh Ki od roku 1994 je zřejmý z obr. 6. U průměru se zde jedná o prostý aritmetický průměr hodnot z př́lohy č. 41.

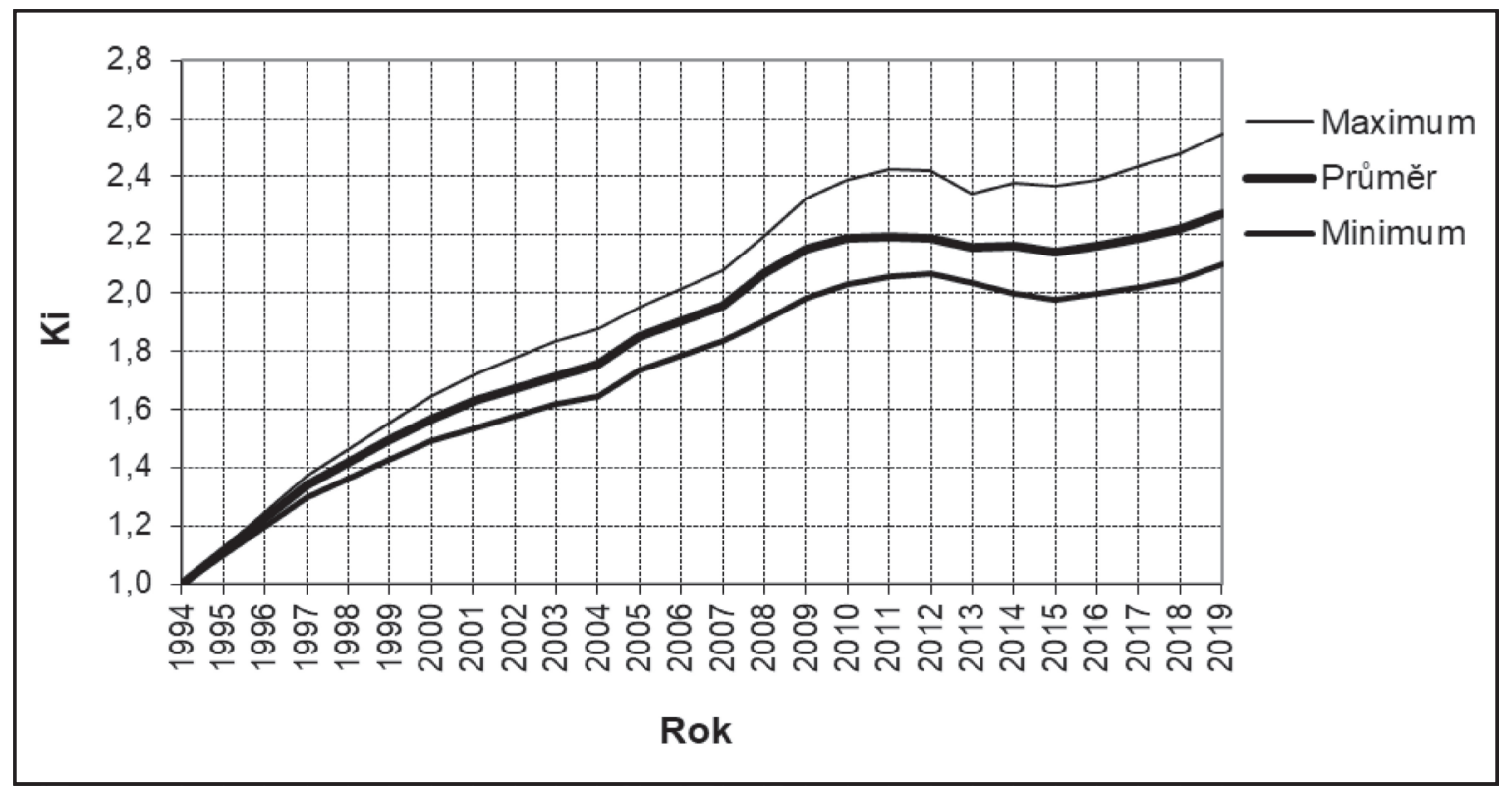

Obr. 6 Vývoj koeficientu změny cen staveb Ki v letech 1994-2019.

Fig. 6 Evolution of factor changes in prices of constructions Ki in the years 1994 to 2019. 


\section{OCEŇOVÁNÍNÍ KOMBINACÍ NÁKLADOVÉHO A VÝNOSOVÉHO ZPU゚SOBU}

§ 31 až $§ 33$ - beze změn.

Př́loha č. 22 - Míry kapitalizace - beze změn.

Př́íloha č. 23 - Zatř́ídění nemovité věci do skupiny podle analýzy jejího rozvoje pro ocenění kombinací nákladového a výnosového způsobu - beze změn.

\section{OCEŇOVÁNí STAVEB POROVNÁVACÍM ZPŮSOBEM}

§ 34 až $§ 38$ - text beze změn.

Př́lohy č. 24 až 27, týkající se ocenění staveb porovnávacím způsobem: u všech jsou nové základní ceny. Aktualizace byla provedena na základě analýzy údajů, které Ministerstvu financí předávají územní pracoviště finančních úřadů v návaznosti na ustanovení § 33 odstavec 3 zákona č. 151/1997 Sb., o oceňování majetku, ve znění pozdějších předpisů. Na grafech v obr. 7,8 , 10 až 12 je uveden vývoj ZC od roku 2009 (zavedení ocenění porovnávacím způsobem) do roku 2019 (dřive tzv. IPC indexovaná průměrná cena; s přechodem na $\mathrm{ZC}$ a změnou metodiky zřejmě souvisejí skoky od roku 2013). U průměru se zde jedná o prostý aritmetický průměr hodnot z př́slušných př́loh. Graf na obr. 9 zobrazuje současné jednotkové ceny bytů za $\mathrm{m}^{2}$ podlahové plochy v jednotlivých krajích.

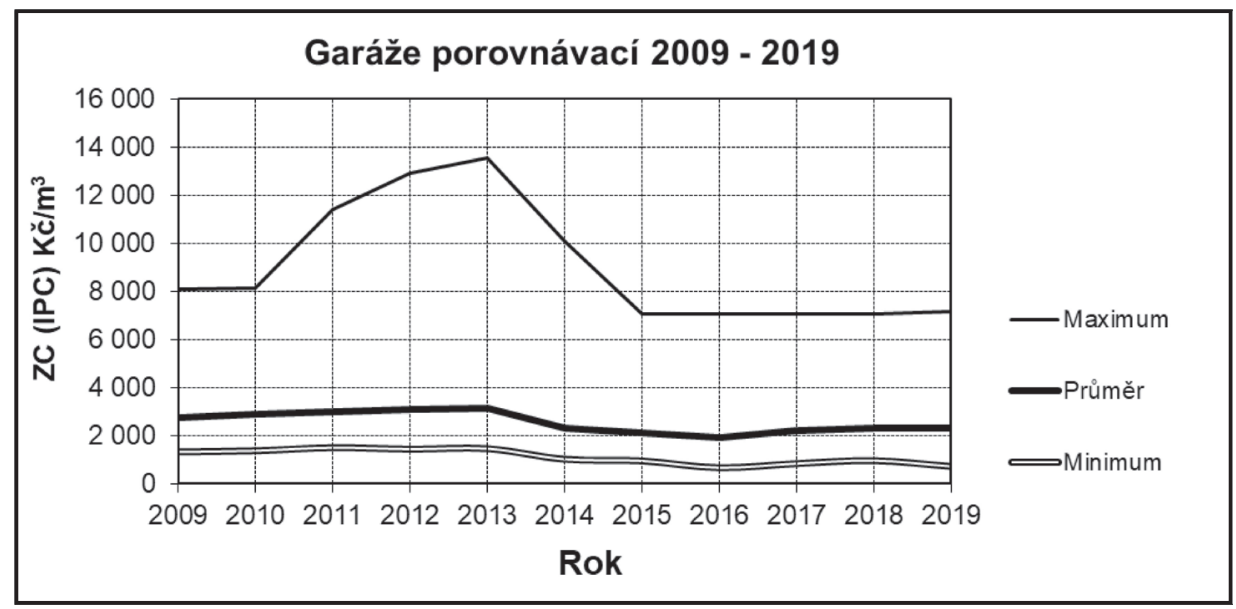

Obr. 7 Vývoj základních cen ZC u porovnávaci metody v letech 2009-2019; garáže.

Fig. 7 Evolution of basic prices ZC with comparative methods in the years 2009-2019; garage.

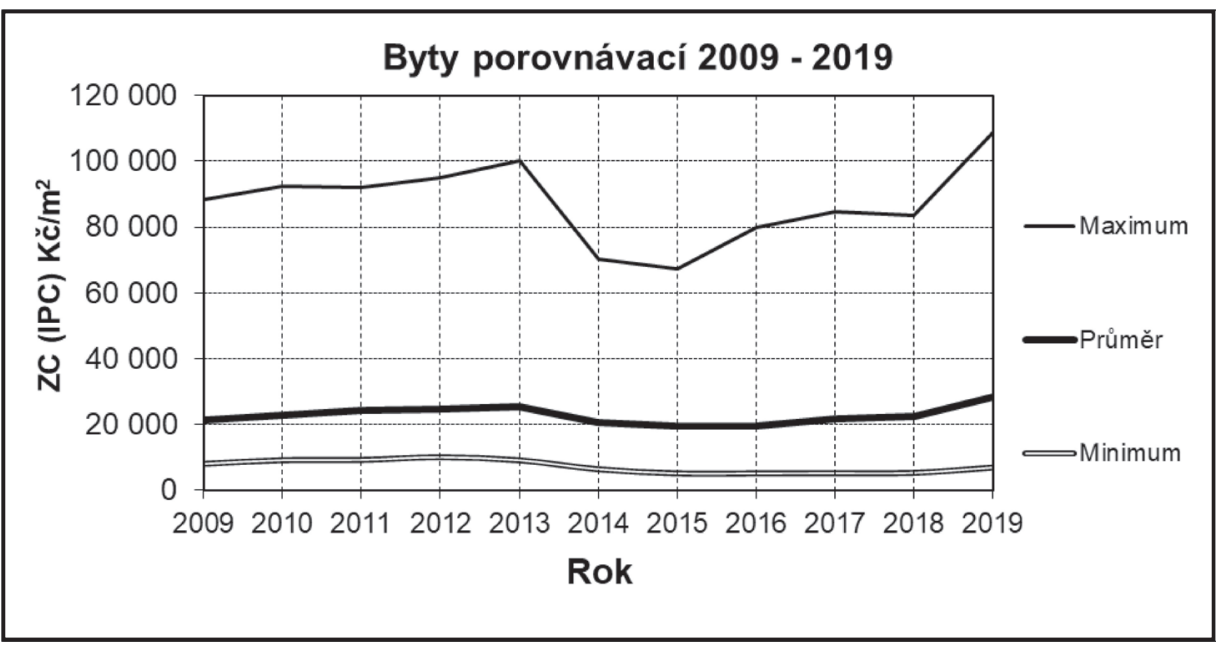

Obr. 8 Vývoj základních cen ZC u porovnávací metody v letech 2009-2018; byty.

Fig. 8 Evolution of basic prices ZC with comparative methods in the years 2009-2018; flats. 


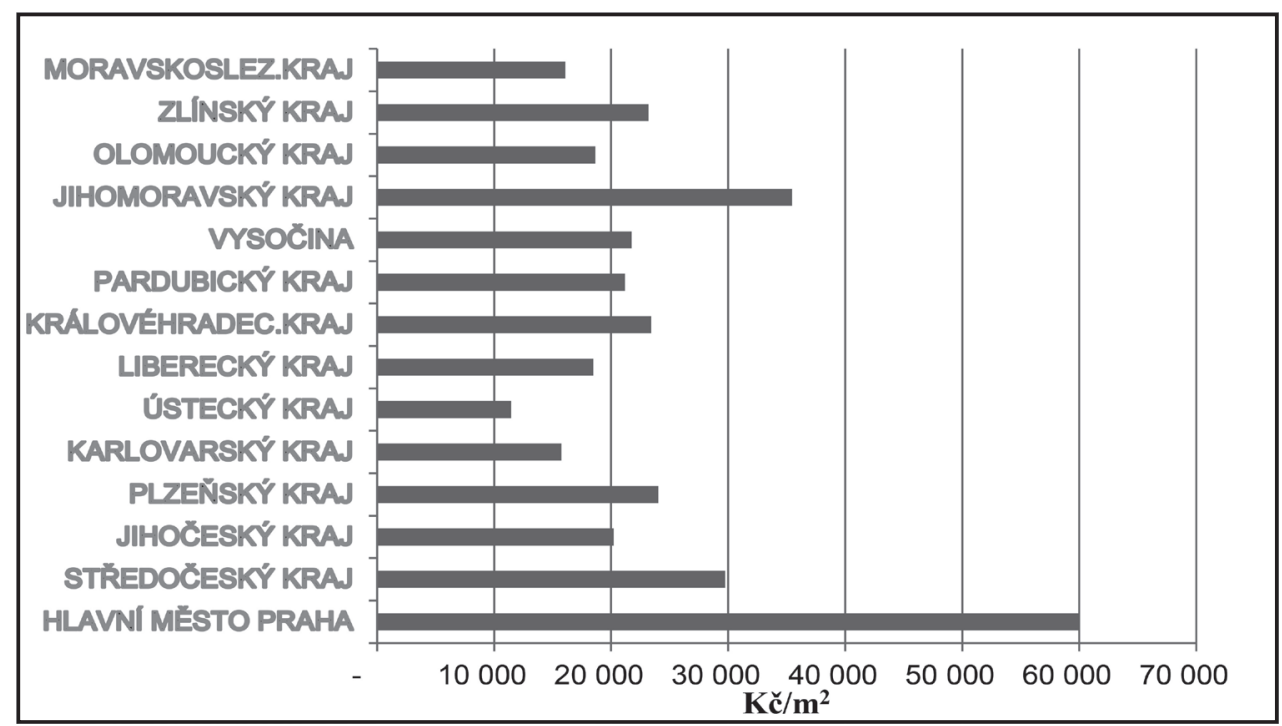

Obr. 9 Prưměrné ceny podlahové plochy bytu podle krajův Kč/m² (Pramen: Důvodová zpráva MF ČR 2019).

Fig. 9 Average prices of apartment floor space by region in CZK/ $\mathrm{m}^{2}$ (Source: Explanatory Memorandum of the Ministry of Finance 2019).

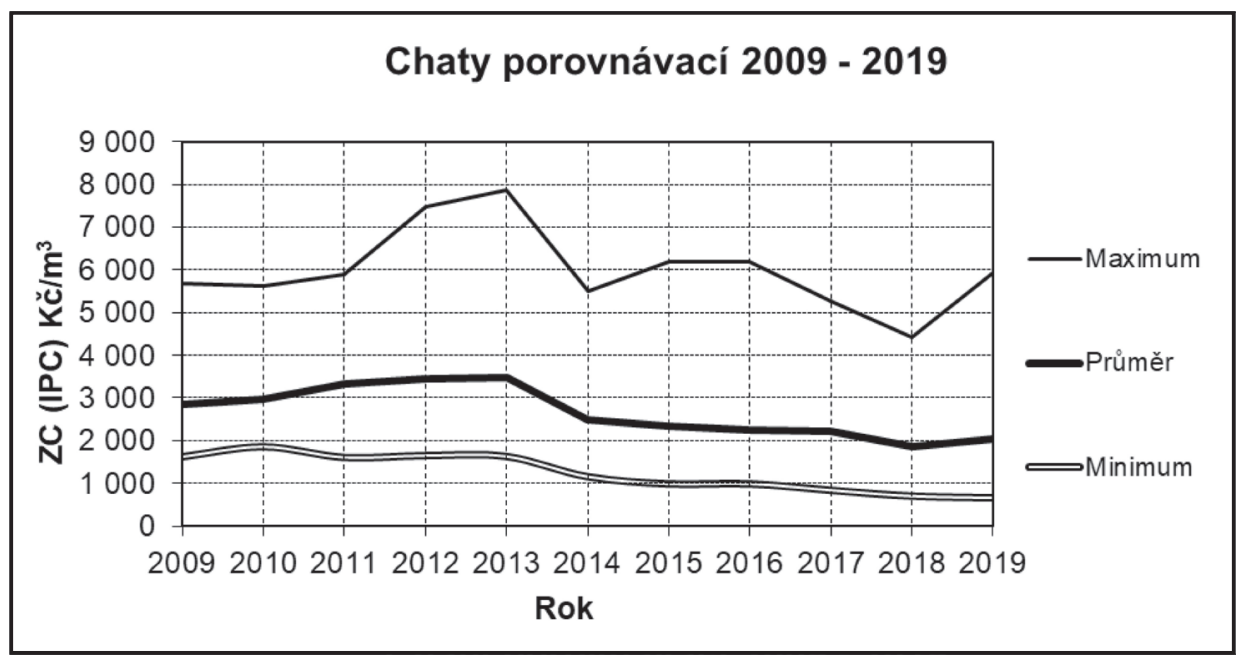

Obr. 10 Vývoj základnich cen ZC u porovnávaci metody v letech 2009-2018; rekreační a zahrádkářské chaty.

Fig. 10 Evolution of basic prices ZC with comparative methods in the years 2009-2018; recreational and gardening cottages.

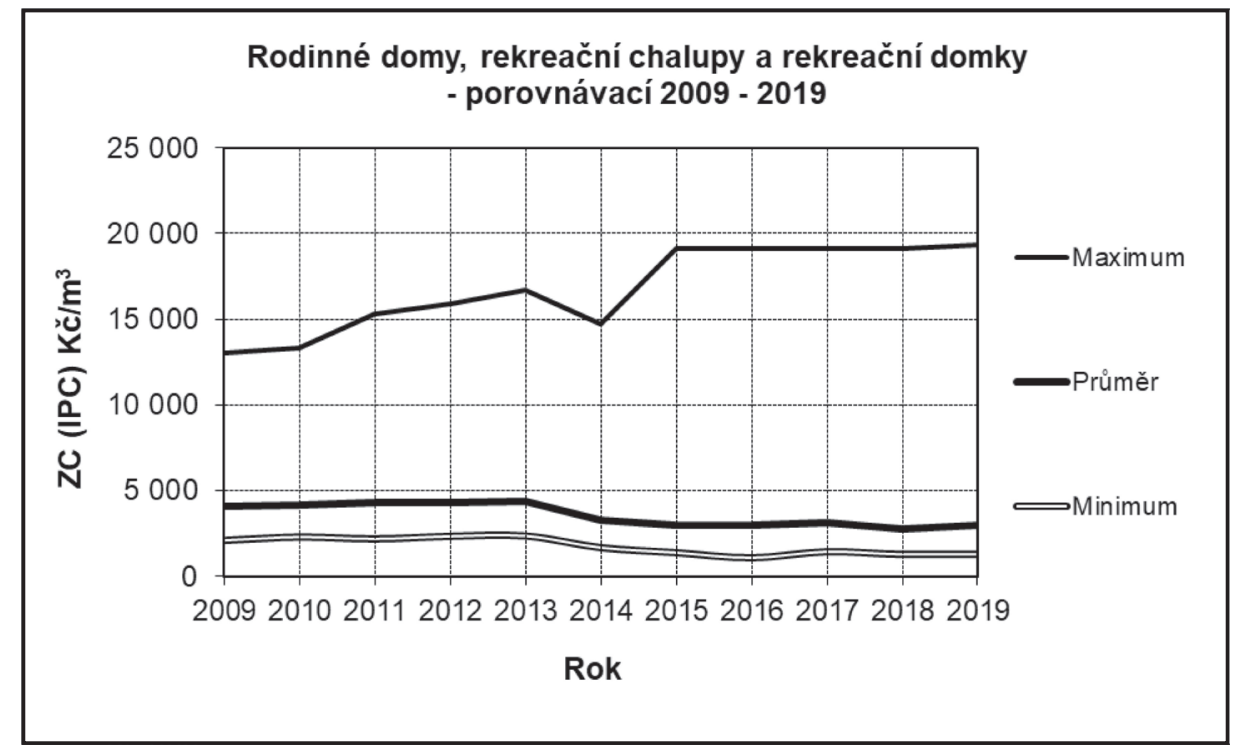

Obr. 11 Vývoj základních cen ZC u porovnávaci metody v letech 2009-2018; rodinné domy, rekreační chalupy a rekreační domky.

Fig. 11 Evolution of basic prices ZC with comparative methods in the years 2009-2018;family houses, vacation cottages and recreational houses. 
Tab. 2 Přehled meziročních př́růstků průmèru ze základnich cen u porovnávacího způsobu ocenèní v letech 2010-2019.

Tab. 2 Overview of annual growth averages from basic prices by reference to the valuation in the years 2010-2019.

\begin{tabular}{lcccccccccc}
\hline \multicolumn{7}{c}{ Přírůstek průměru ze ZC u porovnávacího způsobu ocenění staveb v daném roce oproti roku předchozímu (\%) } \\
\hline Rok & 2010 & 2011 & 2012 & 2013 & 2014 & 2015 & 2016 & 2017 & 2018 & 2019 \\
Garáže & 4,45 & 4,23 & 2,26 & 1,46 & $-26,46$ & $-8,45$ & $-7,99$ & 13,13 & 5,03 & 0,74 \\
Byty & 7,68 & 5,54 & 2,67 & 2,19 & $-18,34$ & $-6,4$ & 0,74 & 11,8 & 2,86 & 26,95 \\
Chaty & 4,39 & 11,74 & 3,73 & 1,18 & $-28,0$ & $-6,43$ & $-3,31$ & $-2,16$ & $-15,75$ & 9,39 \\
$\begin{array}{l}\text { Rodinné domy, rekreační chalupy } \\
\text { a domky }\end{array}$ & 1,05 & 4,62 & 0,02 & 1,55 & $-24,8$ & $-8,96$ & $-1,93$ & 6,58 & $-12,29$ & 8,82 \\
\hline
\end{tabular}

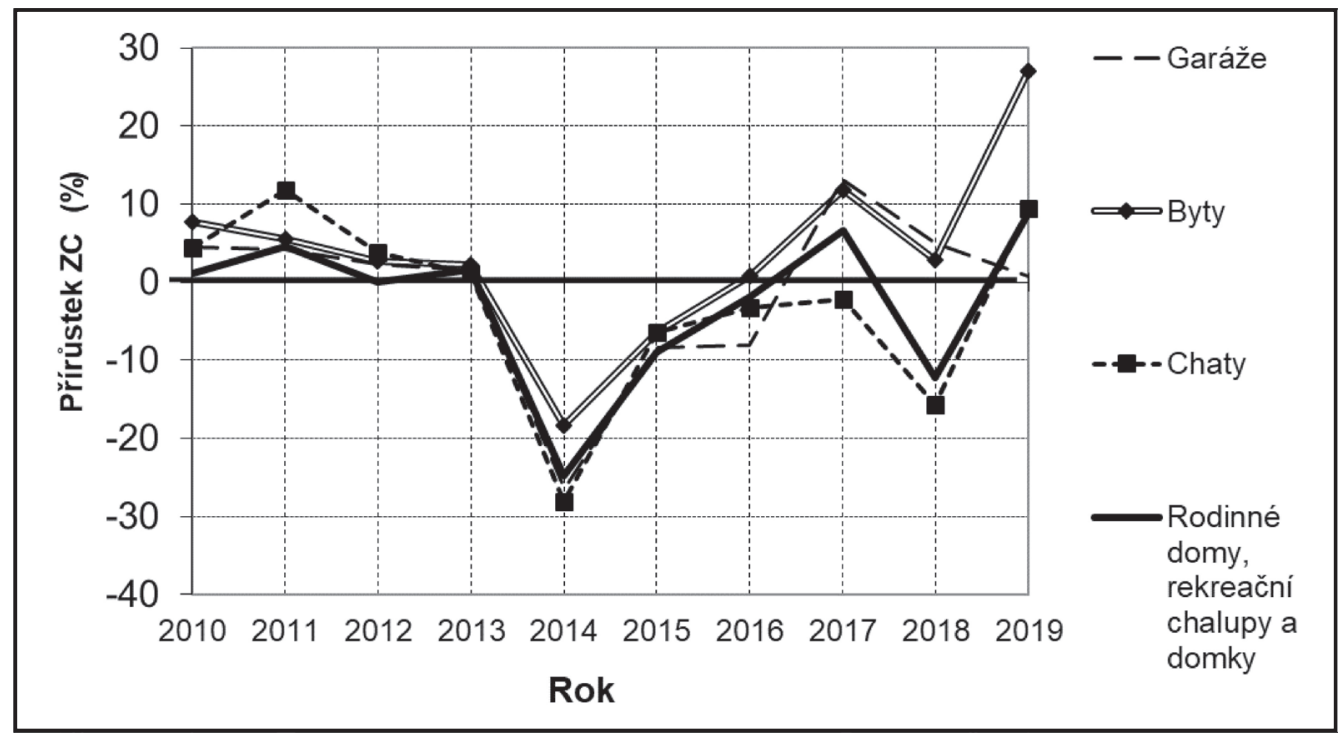

Obr. 12 Vývoj meziročního př́růstku průmèru základni ceny u porovnávací metody v letech 2010-2019.

Fig. 12 Evolution of annual increase in the average basic price by comparison methods in the years 2010-2019.

\section{OCEŇOVÁNÍ PRÁVA STAVBY}

§ 39 - Oceňování práva stavby: beze změn. Změna v § 29a, jenž nyní zní: Cena stavby, poprípadějednotky, které jsou součástí práva stavby, se určí podle §10 až 30. To neplatí v připadě oceněni stavby pro určení výše náhrady, pokud bylo ve smlouvě ujednáno jinak.

\section{OCEŇOVÁNÍ TRVALÝCH POROSTŮ}

\section{$\S 40$ až $§ 47$ - Oceňování trvalých porostů:}

- $\quad$ \$ 42 odst. 3: Nově se umožňuje aplikovat srážku lesních porostů až do výše $85 \%$ v případě plošně odumírajících a plošně odumřelých lesních porostů, jsou-li splněny podmínky pro uplatnění více druhů srážek.

- $§ 45$ odst. 1: Do ustanovení § 45, který upravuje oceňování lesních porostů zjednodušeným způsobem pro daňové účely, byl doplněn text, který umožňuje v případě plošně odumírajících a plošně odumřelých lesních porostů neplnící produkční funkci lesa (např. kůrovcové souše, ohořelé kmeny stromů), zohlednit tuto skutečnost $v$ jeho ceně. $\mathrm{V}$ těchto prŕpadech lze $\mathrm{v}$ ocenění postupovat nově podle ustanovení § 40 až 42.

Př́ilohy č. 28 až 40, týkající se ocenění trvalých porostů- beze změn.

\section{DALŠí USTANOVENÍ}

§ 48 (Oceňování majetkových práv) - beze změn.

§ 48a - Zatřídění pro určení indexu polohy - beze změn.

$\$ 49$ (Věcná břemena): beze změn.

\$ 50 (Zaokrouhlování): beze změn.

§ 51 (Územní plány): beze změn.

\$ 52 (Jednotky podle jednotlivých zákonů): beze změn.

§ 53: V odstavci 1 a 2 byl stanoven jednoznačně postup pro určování počtu obyvatel obce. Nově se vychází nikoliv z údajů Malého lexikonu obcí ČR, ale z údajů o počtu obyvatel v obcích, zveřejňovaných na internetových stránkách Českého statistického úřadu k 1. lednu jednotlivých roků, což byl požadavek Legislativní rady vlády. Český statistický úřad aktualizuje tyto údaje až v dubnu, tedy $\mathrm{v}$ průběhu předmětného roku, proto $\mathrm{z}$ hlediska ocenění je nutno vycházet $\mathrm{z}$ údajů o obcích $\mathrm{k} 1$. lednu kalendářního roku předcházejícího roku, ke kterému se ocenění provádí. Tyto údaje korespondují s údaji Malého lexikonu ČR, a proto není potřeba řšit přechod na jinou databázi.

V ustanovení se řeší i případy, kdy v průběhu roku došlo ke změně území obce, která není uvedena $\mathrm{v}$ uvedené databázi. V těchto případech se při určení počtu obyvatel vychází ze stavu dle evidence obyvatel $\mathrm{k} 1$. lednu roku, ke kterému se ocenění provádí. 
Nově také novela oceňovací vyhlášky zakotvuje určování nezaměstnanosti obce. Navrhuje se určovat tento údaj, obdobně jako u určování počtu obyvatel v obci, podle stavu k 1 . lednu roku, ve kterém se nemovité věci oceňují, podle údajů zveřejněných na internetových stránkách na Integrovaném portálu Ministerstva práce a sociálních věcí, a to ve „Statistiky nezaměstnanosti z územního hlediska“ (https://portal.mpsv.cz/sz/stat/nz/uzem). Jde o zjednodušení ocenění.

§ 54: beze změn.

Tabelární přehled vztahů pro ocenění od 1 . srpna 2019 je uveden v publikaci Úřední oceňování majetku 2019 (www.cerm.cz).

\section{LITERATURA}

[1] BRADÁČ, A., POLÁK, P. Úřední oceňování majetku 2019. 1. vydání. CERM, Brno, 2019, 323 s. ISBN 978-80-7623-013-2.

[2] Vyhláška č. 188 Sb., kterou se mění vyhláška č. 441/2013 Sb., k provedení zákona o oceňování majetku (oceňovací vyhláška), ve znění pozdějších předpisů.

[3] Ministerstvo financí - Odůvodnění novely pro LRV - 2019.

\section{Správná citace:}

BRADÁČ, A., POLÁK, P. Změny předpisů pro oceňování věcí nemovitých od 1. srpna 2019. Soudní inženýrství, 2019, 30(3), 51-61. DOI: http://dx.doi.org./10.13164/SI.2019.3.51. ISSN 1211-443X.

\section{Errata publikace Úřední oceňování majetku 2019}

Na str. 75 v př́loze č. 8 v řádcích J a K v posledním sloupci je text, který tam nepatří, zůstal z minulé verze ÚOM 2018. Platilo to do 31. 7. 2019. V nové verzi ÜOM je sloupec s Ki vypuštěn. ale toto autor přehlédl. Buňky by měly být prázdné. 